\title{
The agricultural crops production profitability in modern conditions
}

\author{
Kirill Zhichkin ${ }^{1, *}$, Vladimir Nosov ${ }^{2,3}$, Lyudmila Zhichkina ${ }^{1}$, Vyacheslav Zhenzhebir ${ }^{2}$, and \\ Svetlana Rubtsova ${ }^{4}$ \\ ${ }^{1}$ Samara State Agrarian University, 2, Uchebnaja str., 446442, Kinel, Russia \\ ${ }^{2}$ K.G. Razumovsky Moscow State University of technologies and management, 73, Zemlyanoy val, \\ 109004, Moscow, Russia \\ ${ }^{3}$ Academy of the Investigative Committee of the Russian Federation, 12, Vrubel Str., 125080, \\ Moscow, Russia \\ ${ }^{4}$ Saratov State Vavilov Agrarian University, 1, Teatralnaya square, 410012, Saratov, Russia
}

\begin{abstract}
The article discusses the issues of determining the crop production profitability, which may arise when assessing agricultural land in the Samara region. When evaluating profitability, it is necessary to take into account revenue, cost of production. Moreover, taking into account factors for a short-term period (1 year) does not give a real picture, so in the context of counter-sanctions, when agricultural producers are in favorable conditions, an increased value of profitability is noted, which is impossible in the long term.
\end{abstract}

\section{Introduction}

Production profitability is calculated as the ratio of profit from sales to the costs of goods production and sales sum [1-5]. The coefficient shows how much profit the company has from each ruble spent on the production and sale of products. This indicator can be calculated both as a whole for the enterprise, and for its individual units or types of products $[6,7]$.

\section{Methods and Materials}

From a methodological point of view, it is necessary to distinguish between actual and estimated profitability. The determination of actual profitability is carried out in order to verify the return on costs incurred, to establish systematic control over the development of the project and, if necessary, adjust it. Estimated profitability is determined in the preparation and justification of projects, as well as the implementation of individual actions (activities) [8-11].

Actual profitability allows you to determine the real result, the degree of utility for the development of social production. In the implementation of organizational and economic measures, it manifests itself immediately after the transfer of the project to nature and the

* Corresponding author: zskirill@mail.ru 
implementation on this basis of an appropriate restructuring of the economy (breaking the crop rotation array into fields and work areas, adapting them for the efficient operation of agricultural machinery; placing crops on the most suitable for them soils, the approximation of labor-intensive crops to economic centers, etc.) [12-18].

Actual and estimated profitability may not coincide for the following reasons.

Firstly, the estimated profitability is determined at the time of the project full development according to the planned crop yield indicators, production costs, etc. Actual profitability depends on the prevailing weather conditions and other natural and economic factors.

Secondly, the estimated profitability is based on the whole system of measures related to capital investments, which are supposed to be carried out by the project period end, and the actual one consists only of those that were fully or partially implemented at the assessment time.

Thirdly, the actual profitability value depends on the really spent funds, the timing of the various engineering structures commissioning, while the estimated size is evaluated according to consolidated standards [19-23].

\section{Results and Discussion}

In this case, we will focus on determining the estimated profitability. In the agricultural production case, and specifically the production of crop products, profitability calculation includes the income and expenditure determination.

The income part is formed mainly from the crop products sale proceeds, which can be adjusted taking into account the cultivated products marketability. To calculate the marketability value, you can use the form of the grain balance, including the harvested area under all crop rotation crops, the planned yield, the each crop gross yield, the estimated consumption of the resulting products (dead waste, seeds of own production, feed, expenses for on-farm needs, in-kind wages, rental payments, etc.) (tab. 1). The remaining quantity of products will form commercial output, and generate revenue [24].

Table 1. Grain balance form*.

\begin{tabular}{|c|c|c|c|c|c|}
\hline \multirow{2}{*}{ Crop } & \multirow{2}{*}{$\begin{array}{l}\text { Harvested } \\
\text { area, ha }\end{array}$} & \multirow{2}{*}{$\begin{array}{c}\text { Productivity, } \\
\text { t/ha }\end{array}$} & \multirow{2}{*}{$\begin{array}{l}\text { Gross } \\
\text { yield, } \mathrm{t}\end{array}$} & \multicolumn{2}{|c|}{ Consumption } \\
\hline & & & & dead waste, $\mathrm{t}$ & own seeds, $\mathrm{t}$ \\
\hline \multirow[b]{2}{*}{ Crop } & \multicolumn{4}{|c|}{ Consumption } & \multirow[b]{2}{*}{$\begin{array}{c}\text { Commercial } \\
\text { output, } \mathrm{t}\end{array}$} \\
\hline & feed, $t$ & $\begin{array}{c}\text { in-kind } \\
\text { compensation, } \mathrm{t}\end{array}$ & $\begin{array}{l}\text { lease } \\
\text { rents, } \mathrm{t}\end{array}$ & $\begin{array}{c}\text { other intercompany } \\
\text { needs, } t\end{array}$ & \\
\hline & & & & & \\
\hline
\end{tabular}

*Note: the dead waste rate is $5-10 \%$ of the bunker mass, depending on the type of grain being harvested; the mass of own seeds is equal to the product of the planned sowing area and the sowing rate $(\mathrm{t} / \mathrm{ha})$; calculation of feed depends on livestock, formulation, feed used and feeding period; calculation of in-kind wages is prescribed in the Regulation on wages at the enterprise; the amount of lease payments is determined in accordance with land lease agreements (primarily).

Selling price. The price information source can be data from the Federal State Budgetary Institution "Specialized Center for Accounting in the Agro-Industrial Complex" (specagro.ru). It presents both weekly analytical market reviews and price monitoring by type of agricultural product, by region and accounting date.

The expenditure part (cost) is formed on the basis of the used technology, a set of equipment and the resources cost. 


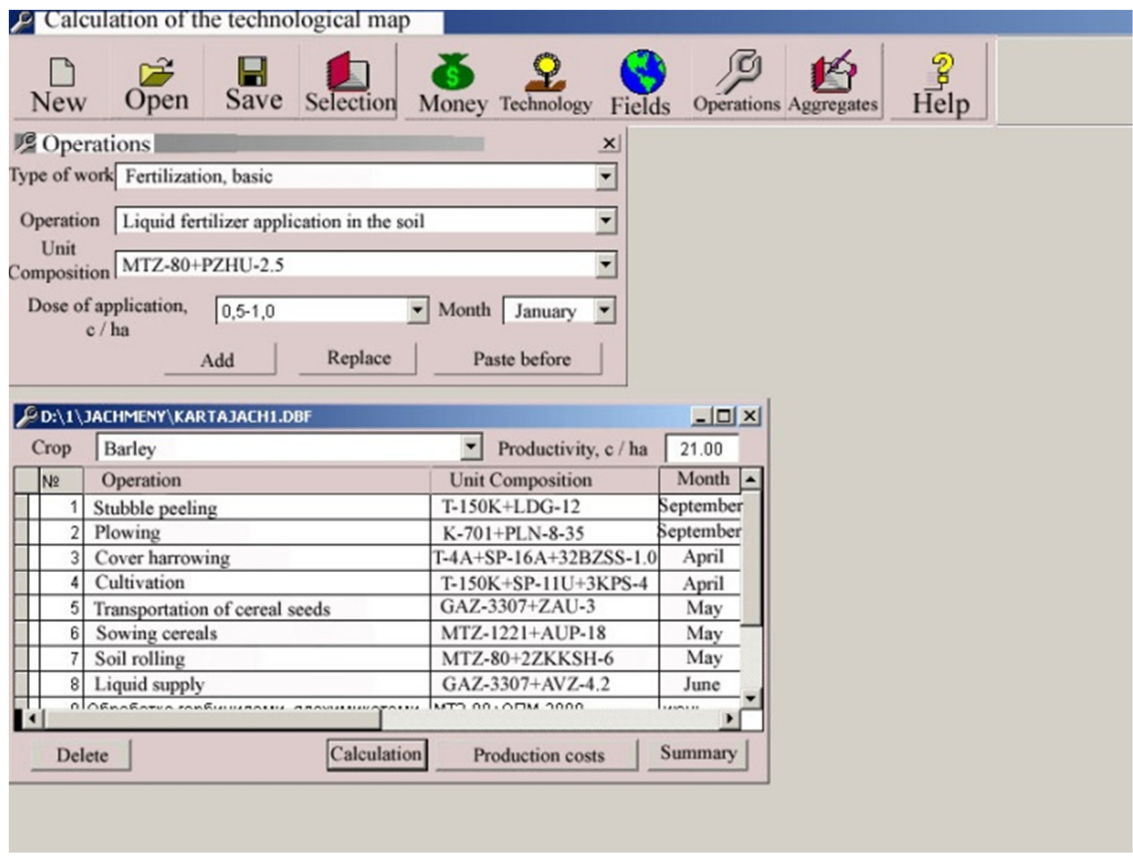

Fig. 1. An example of filling in the initial information for calculating the technological map in crop production.

From the view point of technology, there are currently three main areas: traditional (using plowing), minimal (using disking) and zero (when sowing on stubble). Using these three approaches implies the use of equipment various sets, the multiplicity of the fields chemical and mechanical treatments. Depending on the used technology, the structure and the magnitude of the growing crops cost can vary significantly, which makes it difficult to use common approaches to determining costs. In crop production, technological maps for the crops cultivation are widely used to calculate costs. The algorithm for their calculation is well developed, which allows you to use numerous programs for calculating technological maps (total costs) for the cultivation of crops (per 1 ha, for a given area), production costs and the products cost for 1 cwt. Such softwares are widespread (for example, 2 similar softwares have been developed in the Samara State Agrarian University). The difference between them mainly consists in the convenience of entering the source data. (Fig. 1, 2, 3).

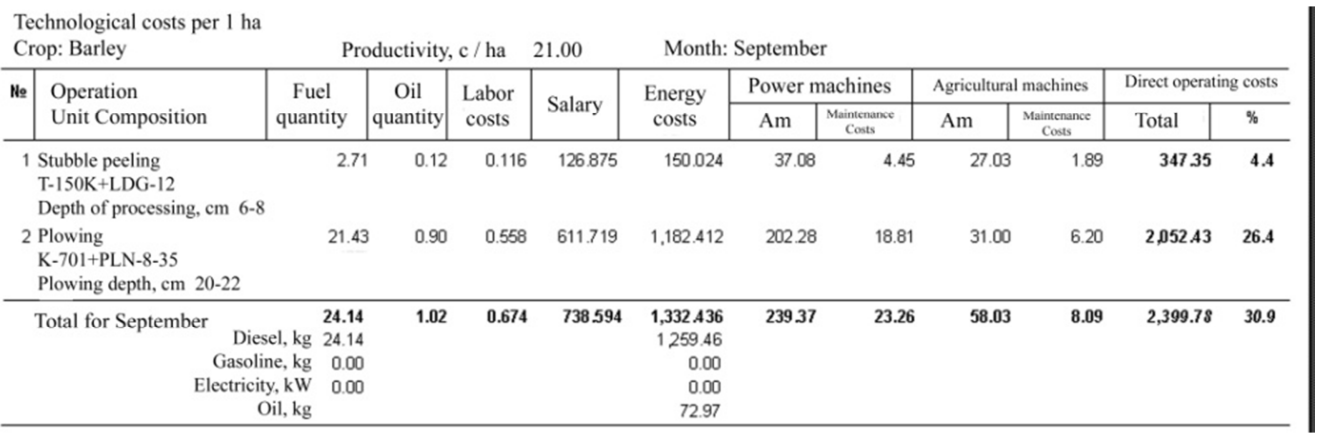

Fig. 2. Final report. Calculation of direct operating costs for growing crops. 
The data thus obtained can be used to calculate profitability in crop production for each crop and for each individual field.

According to the official data by the territorial body of the Federal State Statistics Service for the Samara region, it follows that there are no statistical data on the profits distribution between the agricultural land owner and an entrepreneur in the Samara region.

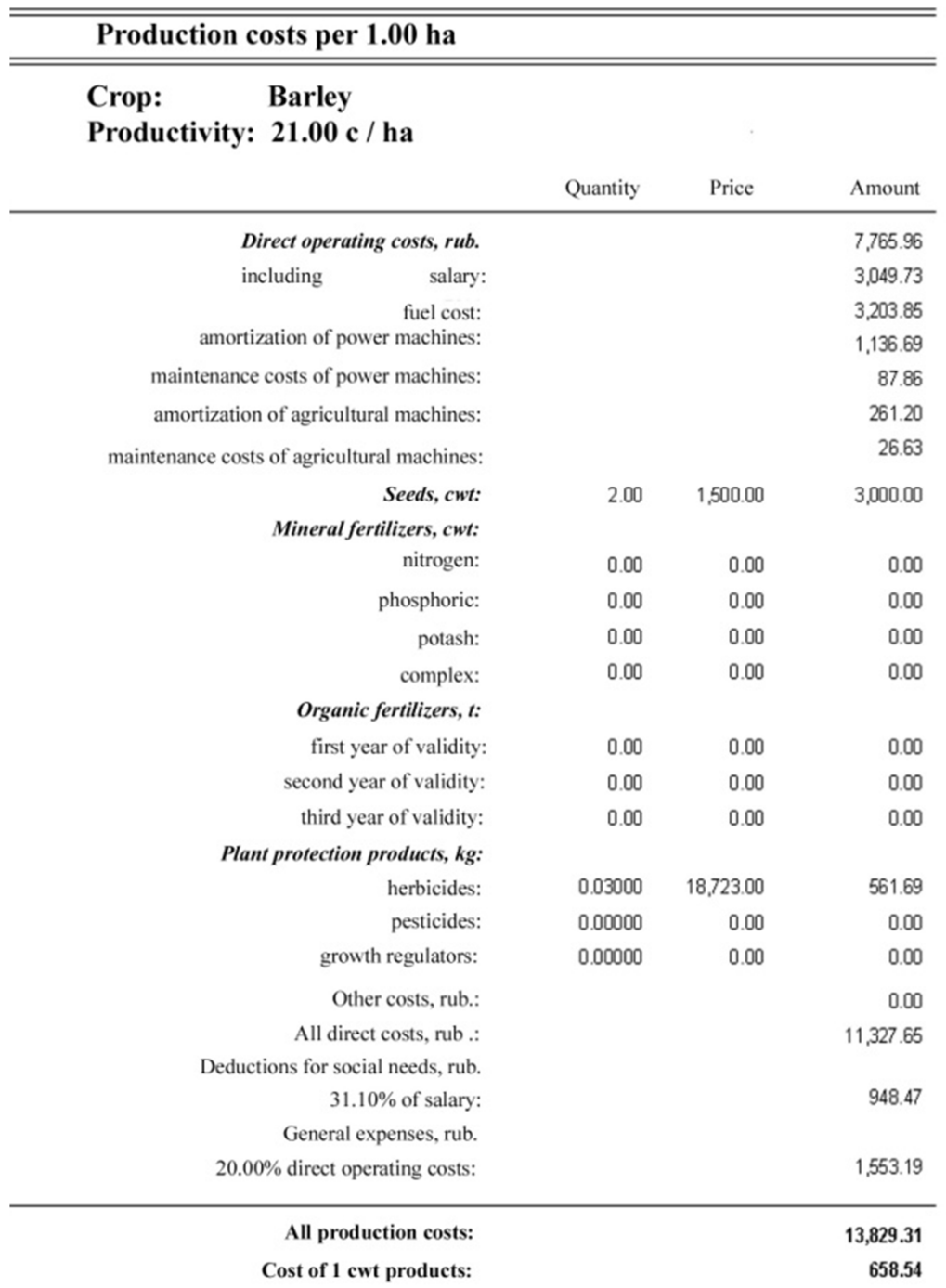

Fig. 3. The final report. Calculation of costs for the planned area and the cost of $1 \mathrm{cwt}$ production for growing crops.

In the process of conducting the agricultural land current cadastral valuation, the data by the Federal Statistical Service were used, namely, the general profitability (by type of activity "Agriculture, Hunting, Forestry" for 2010, taking into account small businesses), which at that time was $5 \%$. Therefore, it was decided to take the average entrepreneur profit of equal overall profitability in the type of activity "Agriculture, Hunting, Forestry" in the amount of $5 \%$. 
Table 2. The financial results of organizations operating in agriculture, hunting and the provision of services in these areas.

\begin{tabular}{|c|c|c|c|c|c|c|c|}
\hline Indicator & $\mathbf{2 0 0 9}$ & $\mathbf{2 0 1 3}$ & $\mathbf{2 0 1 4}$ & $\mathbf{2 0 1 5}$ & $\mathbf{2 0 1 6}$ & $\mathbf{2 0 1 7}$ & $\mathbf{2 0 1 8}$ \\
\hline $\begin{array}{c}\text { The proportion of unprofitable } \\
\text { organizations as a percentage of } \\
\text { the organizations total number }\end{array}$ & 36.2 & 32.6 & 22.9 & 21.6 & 20.7 & 17.7 & 17.1 \\
\hline amount of loss, m. rubles & 2466 & 2458 & 3073 & 1375 & 3158 & 3043 & 2436 \\
\hline $\begin{array}{c}\text { Profitability of sold products } \\
\text { (works, services), organizations } \\
\text { engaged in activities, \%: }\end{array}$ & -1.4 & 5.0 & 7.5 & 12.9 & 13.2 & 17.5 & 29.5 \\
\hline in crop production & -5.2 & 16.5 & 14.1 & 18.0 & 22.0 & 27.5 & 42.5 \\
\hline in livestock & 2.8 & -9.2 & -2.0 & 7.1 & 0.6 & 2.6 & 8.8 \\
\hline
\end{tabular}

Starting from 2014, the table "Financial results of organizations operating in agriculture, hunting and the provision of services in these areas" was included in the statistical compilation "Agriculture in the Samara region", which presents data on the Samara region (table 2). According to these data, at the moment it is possible to trace the profitability in crop production, livestock breeding or in agriculture in general from 2009 to 2018. In our opinion, to use profitability in order to determine the entrepreneur's profit in agriculture, when the profitability of production varies widely (for example, in crop production from $9.8 \%$ to $42.5 \%$ ), depending on a number of reasons, ranging from natural and climatic conditions and ending with speculative games to lower prices, it is necessary to use the average value over a long period, commensurate with the fixed assets applying duration purchased for the commercial project implementation [25-27]. In our case, you can use the arithmetic mean value for 7 years. For agricultural projects in general, profitability will be $12.0 \%$, for crop production - $19.3 \%$. In general, if there is retrospective data for crop production, it is advisable to calculate profitability for a period of 7-10 years (here the main amount of investment costs is the machinery and equipment purchase), in the case of livestock production, depending on the project objectives: construction and reconstruction 15-20 years, the herd replenishment $-5-7$ years.

\section{Conclusion}

Determining the entrepreneur's profit is an important point in the formation of the agricultural land cadastral value [28, 29]. When assessing land conducted in the Samara region in 2012, the entrepreneur's profit was estimated at $5 \%$. In the future, as a result of favorable market conditions, the agricultural production profitability has grown up, which also indicates the increase in the agricultural land estimated value.

\section{References}

1. S. Wolfert, L. Ge, C. Verdouw, M.-J. Bogaardt, Agricultural Systems 153, 69-80 (2017) doi: 10.1016/j.agsy.2017.01.023

2. K. Zhichkin, V. Nosov, L. Zhichkina, Zh. Dibrova, T. Cherepova, IOP Conference Series: Earth and Environmental Science 315, 022023 (2019) doi:10.1088/1755$1315 / 315 / 2 / 022023$.

3. F. Terribile, A. Agrillo, A. Bonfante, G. Buscemi, M. Colandrea, A. D'Antonio, R. De Mascellis, A. Basile, Solid Earth 6(3), 903-928 (2015) doi: 10.5194/se-6-903-2015 
4. K. Czimber, B. Gálos, Scandinavian Journal of Forest Research 31(7), 664-673 (2016) doi: 10.1080/02827581.2016.1212088

5. L. Rickards, S.M. Howden, Crop and Pasture Science 63(3), 240-250 (2012) doi: 10.1071/CP11172

6. O.V. Mamai, I.N. Mamai, M.V. Kitaeva, Digital Age: Chances, Challenges and Future 84, 359-365 (2020)

7. D.C. Rose, W.J. Sutherland, C. Parker, M. Lobley, M. Winter, C. Morris, S. Twining, L.V. Dicks, Agricultural Systems 149, 165-174 (2016) doi: 10.1016/j.agsy.2016.09.009

8. F. Pashaei Kamali, J.A.R. Borges, M.P.M. Meuwissen, I.J.M. de Boer, A.G.J.M. Oude Lansink, Agricultural Systems 157, 118-128 (2017) doi: 10.1016/j.agsy.2017.07.013

9. K.A. Zhichkin, V.V. Nosov, V.I. Andreev, O.K. Kotar, L.N. Zhichkina, IOP Conference Series: Earth and Environmental Science 341, 012005 (2019) doi:10.1088/1755-1315/341/1/012005

10. N. Rada, W. Liefert, O. Liefert, Journal of Agricultural Economics 71(1), 96-117 (2020) doi: 10.1111/1477-9552.12338

11. R. Bokusheva, H. Hockmann, S.C. Kumbhakar, European Review of Agricultural Economics 39(4), 611-637 (2012) doi: 10.1093/erae/jbr059

12. A. Lakomiak, K.A. Zhichkin, Journal of Physics: Conference Series 1399, 044088 (2019) doi:10.1088/1742-6596/1399/4/044088

13. V. Parsova, O. Mamai, S. Zudilin, Proceedings of $17^{\text {th }}$ International Scientific Conference "Engineering for Rural Developmentt" 17, 624-631 (2018)

14. W.M. Liefert, O. Liefert, Applied Economic Perspectives and Policy 34(1), 37-75 (2012) doi: 10.1093/aepp/ppr046

15. K. Zhichkin, V. Nosov, L. Zhichkina, O. Grigoryeva, V. Kondak, T. Lysova, IOP Conference Series: Earth and Environmental Science 433, 012004 (2020) doi:10.1088/1755-1315/433/1/012004

16. N.E. Rada, S.T. Buccola, Agricultural Economics (United Kingdom) 43(4), 355-367 (2012) doi: 10.1111/j.1574-0862.2012.00588.x

17. W. Cai, International Economic Review 60(1), 387-411 (2019) doi: 10.1111/iere.12357

18. T. Adamopoulos, D. Restuccia, American Economic Review 104(6), 1667-1697 (2014)

19. P. Bento, D. Restuccia, American Economic Journal: Macroeconomics 9(3), 267-303 (2017)

20. N. Guner, A. Parkhomenko, G. Ventura, Review of Economic Dynamics 29, 256-282 (2018)

21. B. Herrendorf, T. Schoellman, American Economic Journal: Macroeconomics 10(2), 123 (2018) doi: 10.1257/mac.20160236

22. T.N. Medvedeva, I.A. Artamonova, I.N. Baturina, E.A. Farvazova, N.V. Roznina, E.G. Mukhina, IOP Conference Series: Earth and Environmental Science 341, 012010 (2019) doi:10.1088/1755-1315/341/1/012010

23. D. Lagakos, M.E. Waugh, American Economic Review 103(2), 948-980 (2013) doi: 10.1257/aer.103.2.948

24. K. Zhichkin, V. Nosov, L. Zhichkina, IOP Conference Series: Earth and Environmental Science 403, 012073 (2019) doi:10.1088/1755-1315/403/1/012073 
25. S.N. Kosnikov, I.V. Khaibullina, M.A. Ignatskaya, V.V. Bakharev, V.N. Pinchuk, International Journal of Applied Business and Economic Research 15(13), 243-253 (2017)

26. G. Mukasheva, K. Zhakisheva, A. Yernazarova, S. Tazhikenova, D. Zhumanova, G. Kurmanova, Journal of Applied Economic Sciences 13(7), 2017-2030 (2018)

27. Y.I. Sigidov, M.S. Rybyantseva, A.A. Adamenko, E.A. Yarushkina, International Journal of Economics and Financial Issues 6(1S), 88-95 (2016)

28. A.K. Subaeva, A.A. Zamaidinov, Journal of Economics and Economic Education Research 17(4), 8 (2016)

29. K. Zhichkin, V. Nosov, L. Zhichkina, V. Zhenzebir, O. Sagina, IOP Conference Series: Earth and Environmental Science 421, 022066 (2020) doi: 10.1088/1755$1315 / 421 / 2 / 022066$ 